\title{
How TNF was recognized as a key mechanism of disease
}

\author{
Ian A. Clark* \\ School of Biochemistry and Molecular Biology, Australian National University, Canberra, ACT 0200, Australia
}

Available online 9 May 2007

\begin{abstract}
This review summarizes the origins of the insight that excess production of pro-inflammatory cytokines caused a constellation of changes that contribute to pathophysiology of disease. This connection was made following the original 1975 TNF (tumor necrosis factor) publication from New York describing how activated macrophages kill tumors. The study caught the eye of a group in London who were trying to understand how the same in vivo macrophage activation would protect mice against the erythrocytic protozoan parasites that cause malaria and babesiosis. Based on collaborative research between these two groups, it was argued in 1981 that TNF and related cytokines initiated events that caused pathology, as well as parasite death within red cells in these infectious diseases. This proved to be a key conceptual advance. It was also argued that the pathology of bacterial sepsis logically had TNF origins. Once TNF was cloned in 1985, allowing its specific analysis in serum and neutralization in vivo, the involvement of this cytokine in infectious disease pathology was pursued by a number of groups. Some researchers found that once "their" cytokine was cloned and sequenced, they had been unwittingly expanding knowledge on TNF for several years. By the late 1980s excess TNF production was proposed to be central to acute systemic viral diseases. This family of cytokines is now at the centre of investigations to understand the mechanisms of acute systemic viral diseases, including influenza and the hemorrhagic viral diseases. With its implication as the master regulator of other inflammatory cytokines in the synovial membrane, TNF has also become the major cytokine in the pathogenesis of chronic inflammatory disease. Its neutralization has proven to be a potent treatment for rheumatoid arthritis and Crohn's disease.
\end{abstract}

(C) 2007 Elsevier Ltd. All rights reserved.

Keywords: Cytokines; Tumor necrosis factor; Malaria; Acute systemic disease

\section{Introduction}

Tumor necrosis factor (TNF) - currently with over 60,000 entries in Pubmed - was first described in 1975 by a group at the Sloan-Kettering Institute who were seeking to understand how in vivo macrophage activation controlled established tumors in mice [1]. They identified tumor necrosis factor, or TNF, as a promising soluble activity in serum. Unexpectedly, this observation opened the door to the unconventional idea that mechanisms of innate immunity and infectious disease pathogenesis function through the same pro-inflammatory cytokine cascades. This account recalls this development from the perspective of a recently completed PhD student who read the original 1975

\footnotetext{
* Tel.: +61 26125 4363; fax: +61 261250313 .

E-mail address: ian.clark@anu.edu.au.
}

TNF paper, and within a year called on the Sloan-Kettering group with an idea for cross-field collaboration.

\section{The primary Sloan-Kettering contribution}

The concept of TNF arose in Lloyd Old's laboratory at the Sloan-Kettering Institute in the years preceding 1975, when, as noted above, the story first appeared in print. The challenge was to understand how both BCG (the Bacillus Calmette-Guérin strain of Mycobacterium tuberculosis) [2] and bacterial lipopolysaccharide (LPS, also known as endotoxin) [3] possessed anti-tumor activity when administered in vivo, but not when exposed directly to tumor cells in vitro. They concluded that the serum of mice experiencing maximal stimulation of the reticulo-endothelial system through administering BCG 2 weeks before receiving a 
small dose of endotoxin (to which such mice are very sensitive) contained a previously unsuspected anti-tumor agent. This material, which they termed TNF could be transferred to kill subcutaneous sarcoma transplants in other mice, and in serum dilutions up to $1: 10^{4}$ killed fibrosarcoma cells (NCTN Clone L929) - but not mouse embyro fibroblasts - in vitro. The activity however was not caused by residual endotoxin [4].

\section{Malaria: the original link between TNF and acute systemic disease}

To set the scene to explain how our group and the SloanKettering group broadened the scope of TNF studies in 1981 by proposing that it was a fundamental cause of acute systemic illness [5], it is necessary to delve a little into aspects of malarial immunity. The first prerequisite was the resurrection - through electron microscopy during a $\mathrm{PhD}$ in 1975 (Fig. 1) - of the 40-year old, unexploited observation that the host response against hemoprotozoan parasites could lead to their death inside circulating red cells [6]. This clearly required a soluble mediator, although antibody production was not implicated. Jean-Louis Virelizier, a virologist colleague, suggested we see if Type II interferon, a newly described soluble mediator [7] (later termed immune interferon, and then interferon-gamma) was involved. Accordingly [7], mice were infected with live BCG several

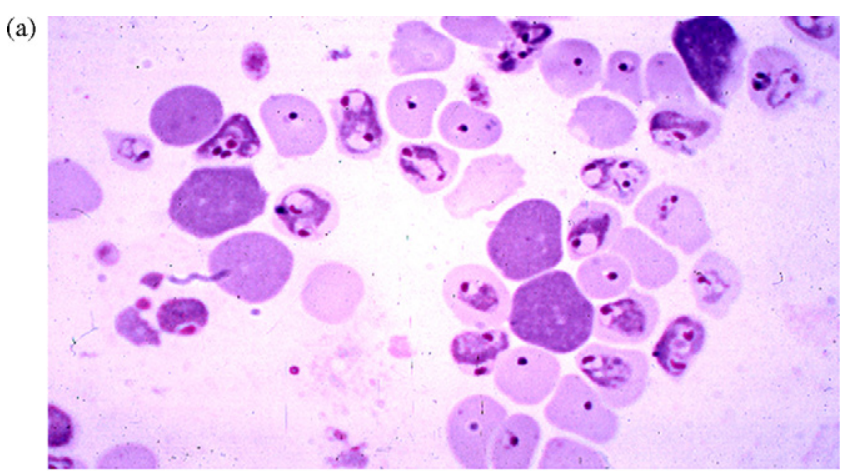

(b) (i)

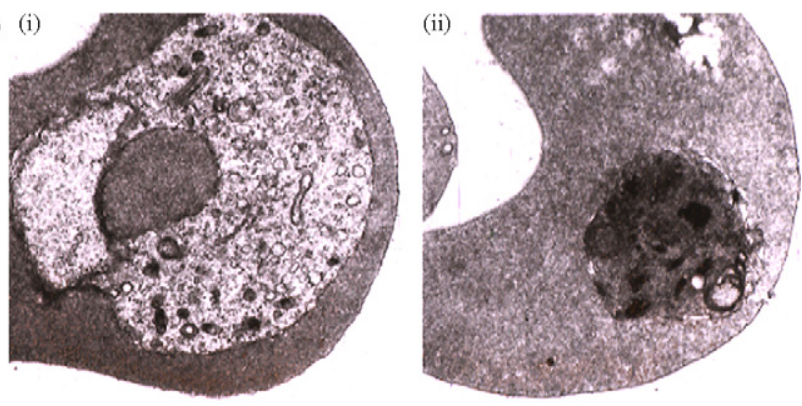

Fig. 1. Aberrant forms of Plasmodium chabaudi immediately post-peak parasitemia in (a) light microscopy of smear of circulating blood that proved, by electron microscopy (b), to be degenerated parasites in erythrocytes. Healthy (i) and degenerate (ii) parasite shown. Prior BCG prematurely caused this same degeneration in Babesia and Plasmodium spp. in mice. weeks before infecting them with hemoprotozoa. This was dramatically protective [8], causing death inside circulating red cells, as in primary infections. These mice proved to possess immunity as strong and durable as that seen in previously infected mice [6].

When Corynebacterium parvum proved to have the same effects [9], it became evident that the host response to hemoprotozoan infections had fundamental similarities to that induced by tumors $[2,10]$, macrophage-dwelling bacteria [11-13] and tissue-dwelling protozoa [14,15]. Historically this type of protection was assumed to act through enhancing phagocytosis of the infectious agents, but since our organisms were dying inside circulating erythrocytes some unidentified circulating soluble factor demonstrably not antibody - was the culprit in our experiments. This raised the idea that the same novel soluble agent(s) was also involved in the immunity against these other organisms.

We next asked what was common to mice treated with BCG, C. parvum and other agents (reviewed in [16]) that have this novel protective activity against hemoprotozoa. One shared characteristic was the capacity to make mice highly susceptible to the harmful effects of parenteral bacterial lipopolysaccharide (LPS). This could be derived from the literature [17-19] as well as our own experiments [20]. Indeed, we could reliably predict which previously untested agents would sensitize mice to LPS by whether they protected them against these blood parasites. Since Plasmodium and Babesia spp. also protected against themselves and each other [21], it was logical that they too should sensitize mice to LPS, and this proved to be so (Table 1). In the process of establishing this we injected LPS into mice during the early stages of malarial infection, while they were apparently normal but very sensitive to this molecule, and found that within a few hours we had inadvertently caused the rapid onset of pathology [22]. The more advanced were the infections with fatal strains of

Table 1

Summary of experiments and reasoning from 1975

\begin{tabular}{llll}
\hline & $\begin{array}{l}\text { Protects } \\
\text { against } \\
\text { parasite }\end{array}$ & $\begin{array}{l}\text { Protects } \\
\text { against } \\
\text { tumors }\end{array}$ & $\begin{array}{l}\text { Increases } \\
\text { susceptibility } \\
\text { to endotoxin }\end{array}$ \\
\hline BCG & + & + & + \\
Cord factor & + & + & + \\
C. parvum & + & + & + \\
Salmonella & + & + & + \\
Brucella & + & + & + \\
Coxiella & + & + & + \\
Zymosan & + & + & + \\
Babesia & + & & + \\
Malaria & + & & +
\end{tabular}

BCG and other macrophage activators, as well as babesia and malaria parasites themselves, protected against these two hemoprotozoa in a manner causing intraerythrocytic death (where antibody could not reach), and all these protective agents sensitized to endotoxin. Thus, a novel endotoxininduced factor of host origin, present in BCG-primed mice, was a plausible culprit. TNF was considered because it fitted these specifications. 
hemoprotozoa, the more minute was the dose of LPS required to rapidly mimic the range of biochemical and pathological changes observed in terminal infections. If we waited longer the same changes occurred without LPS administration [22].

This result implied that malaria infection could duplicate the consequences of LPS injection, and occurred at a time of increasing awareness that LPS might not cause its in vivo toxic effects directly, but through inducing mammalian cells to release harmful soluble mediators. Therefore, these mediators logically were major contributors to these pathological changes in malaria disease as well as those observed in diseases caused by the bacteria that produce LPS. After considering several possibilities, including immune interferon, we became interested in a mediator termed tumor necrosis factor (TNF) in a new paper by Carswell and co-workers from Lloyd Old's group at the Sloan-Kettering Institute in New York. As described above, they were seeking an explanation for the protective effect of BCG and $C$. parvum against experimental tumors [1,23,24]. Like our unknown mediator, theirs was triggered by LPS in mice primed several weeks earlier with BCG or C. parvum, and, like ours, it killed rapidly dividing cells, theirs tumors, ours hemoprotozoa. Therefore, in 1978, we hypothesized the involvement of TNF in the host response against malaria and babesia [22]. The first collaborative experiments with the Sloan-Kettering group showed that malaria infection could take the place of BCG or C. parvum as a primer for TNF and IL-1 generation [5]. Next, serum containing TNF proved to inhibit in vivo multiplication of $P$. vinckei [5]. While we predicted that malaria would provide its own trigger for TNF release based on the LPS experiments [22], we could not detect TNF in terminal malaria serum using the L cell assay of the time. Once this assay had been made more sensitive by adding actinomycin $\mathrm{D}$ we had no difficulty in detecting TNF in such serum [25].

We therefore proposed that, in addition to protecting the host by causing parasites to die inside circulating red cells, TNF and associated mediators, including interleukin-1 (which we referred to by one of its old names, LAF) could harm the host when excessively produced. This, we argued, would explain the fever, hypoglycemia, bone marrow depression, coagulopathy, hypergammaglobulinemia, hypotension and rise in serum levels of acute phase reactants seen in malaria and bacterial sepsis [5,26]. Some 40 key papers demonstrating the development of the idea that TNF was much more than a tumor killer are shown in Table 1 of a 2003 review [16]. In broad terms, this approach led us to the novel concept that the same soluble mediator(s), including and perhaps led by TNF, had a previously unsuspected dual set of functions in disease-governing a new type of protective response against infectious agents, and also causing disease pathology when generated excessively. Some of infectious diseases in which this duality was investigated over the subsequent decade are discussed in Section 4, below.
In these papers $[5,26]$ we predicted that the long-elusive malarial toxin, much written about in the first decade of the 20th century [27] as the probable cause of malarial illness, would prove to be functionally similar to LPS, the only trigger for TNF then known. We argued that the "toxin", like LPS, would not be directly harmful, but act through releasing TNF, and therefore could be defined by its ability to do this in vitro. This led, through development in several laboratories [28,29], to the eventual identification of malarial glycosylphosphatidylinositol (GPI) as a major candidate for the malarial toxin that is released at schizogony (when newly-divided erythrocytic forms of the parasite are released on red cell rupture) and acts by triggering the harmful pro-inflammatory cytokine cascade [30]. Unfortunately, in 2002 those investigating GPI as the malarial toxin went one step further and promoted vaccinating against it to block malarial disease [31], a suggestion that did not take into account that this would also prevent malaria-induced TNF from contributing to the protective response against the pathogen. This duality of the TNF response, the gist of our research 21 years earlier [5], had already (in 2001) become self-evident in patients receiving anti-TNF treatment for rheumatoid arthritis or Crohn's disease. The concept is discussed further in Section 6.2.

The Sloan-Kettering group had included Salmonella sp. in their priming agents and used LPS from this bacterial genus, as well as from Escherichia coli, for their trigger for TNF release. Accordingly, our joint 1981 paper [5] proposed that production of TNF would be enhanced during Salmonella infections, explaining why typhoid can be clinically indistinguishable from severe malaria. This paper also proposed that the Jarisch-Herxheimer reaction arises because antibiotic treatment, on killing the infectious agent, causes it to release a burst of endotoxin-like material that induces the host's cells to generate excessive TNF. Both the typhoid and Jarisch-Herxheimer predictions were subsequently verified by others $[32,33]$.

\section{In vivo effects of rTNF and neutralization of TNF}

Once recombinant TNF had been generated [34] it became possible to test the predictions of TNF mediating both an anti-pathogen response and pathology in malaria and gram-negative bacterial infections [5,26]. The next obvious tools to be developed were specific neutralizing antibodies [35,36], allowing biological questions previously unapproachable to be rapidly addressed by groups with access to the required, but as yet non-commercial, reagents. Many such passive immunisation experiments were performed in vivo, including during experimental LPS toxicity, a common model for sepsis [35], and in vitro (e.g. [37]). Given the unexpected pleotropic activity of TNF, already realised in 1987 [38], the neutralizing antibody against this one cytokine had the potential to nullify a range of known 
activities, bringing them all under the one umbrella. In terms of defining roles of TNF, the outcome was tempered by the large number of functions TNF proved to share with the equally pleotropic interleukin-1 (IL-1) $[38,39]$. Parenthetically, this broad spectrum of functional overlap of TNF and IL-1 was quite unexpected, given their lack of sequence homology and receptor recognition, and shows how little we still know of cytokine biology. On a related matter, recent work in gene-deleted mice [40] implies that earlier anti-TNF antibodies used in a mouse malaria model [41] may have also neutralized lymphotoxin, a related cytokine that has $30 \%$ homology with TNF, and shares one of its receptors.

\subsection{Examining activity of rTNF against pathogens}

While rTNF proved not to harm malaria parasites in vitro [42], it did so in vivo [42,43], implying it is an initiator, rather than an effector, of the host response, inducing the release of a mediator further down the inflammatory chain. Other infectious agents that TNF was shown to inhibit, implying a role in immunity against them, include Mycobacterium spp. [44], Salmonella typhimurium [45], Leishmania spp. [46], Toxoplasma gondii [47], Coxiella brunetii [48], and Listeria monocytogenes [49].

\subsection{Examining role of TNF in host pathology in infectious diseases}

When rTNF first became available to us (a generous gift from Bruce Beutler), we were able to show that, when administered in small quantities to mice carrying low parasitemias of Plasmodium vinckei, it would reproduce the hypoglycemia, mid-zonal liver damage and pulmonary accumulation of neutrophils seen in the terminal stages of this malarial infection [50]. Much less TNF was required to cause this pathology in mice carrying a non-symptomatic low load of malaria parasites, in hindsight because their IFNgamma levels were increased and the two cytokines were synergizing. When injected into mice carrying a nonsymptomatic, low parasitemia, small doses of rTNF also caused fetal loss [51] as well as erythrophagocytosis and dyserythropoiesis [25], all of which are associated with human malaria infection. In principle, these data fulfilled the predictions of 6 or 7 years earlier [26]. Evidence has since been collected, either through administering or neutralising TNF, that implies a role for this cytokine in the pathology of many infectious diseases. To stress the dual role of TNF, involved in both immunity and pathology, the diseases caused by the pathogens referred to in Section 4.1, above, have been selected for inclusion. Accordingly, work on the diseases caused by Mycobacterium spp. [52], Salmonella typhi [53], Leishmania spp. [54], Toxoplasma gondii [55], Coxiella brunetii [56], and Listeria monocytogenes [57] are noted.

The term cachectin warrants discussion here. Inevitably, the sequencing technology applied to TNF was also being used at the same time to define the molecular nature of other chemically purified cytokines. Inevitably, given what is now known about the pleotropic properties of TNF, a number of researchers found that a serum fraction they had named and functionally defined proved to be identical to TNF. One example is cachectin, an LPS-induced macrophage product that came to light in 1982, as yet in an unnamed form [58], through trying to understand weight loss in trypanosomiasis. Its defining characteristic was an ability to inhibit the enzyme lipoprotein lipase, and three years later (a decade after TNF) it was named and purified [59]. Like many other soluble mediators it proved, on sequencing [60], to be identical to a previously sequenced [34] molecule that had been termed TNF ten years earlier [1]. Unfortunately, for some years this group elected to retain the term cachectin as a synonym for TNF, often using it alone. This tended to obscure the literature during their experiments using rTNF and antibody that neutralizes it [61-63] to investigate the role of this cytokine in bacterial sepsis, a role proposed four and five years earlier using the earlier terminology, TNF $[5,26]$. The term cachectin is still occasionally seen in new literature, introducing an unnecessary complexity when reconstructing the true sequence of events that led to the elucidation of sepsis. In contrast, the other researchers who had this experience of realizing that "their" cytokine had already been sequenced under another name gave the term TNF precedence, by virtue of its prior publication and sequencing, and 10 years usage. Those studying differentiation inducing factor (DIF) provide an example of following this convention [64].

\subsection{Inadvertent experiments on the harmful effects of rTNF in man}

The obvious next step once rTNF was available in quantities was to test it therapeutically against tumors in patients, but its harmful side effects limited how much could be administered. Although a grave disappointment in practical terms, the nature of these side effects was a windfall for anyone trying to understand infectious disease pathophysiology. In summary, the headache, nausea, vomiting, fever, rigors, anorexia, hypotension, thrombocytopenia (for example [65]), hypertriglyceridemia [66], low serum iron [65], diarrhea [65,67], coagulopathy [68] (also seen in normal volunteers given TNF [69]), neurotoxicity $[67,70]$ and prostration [67] of malaria were all reported. Anyone familiar with the in vivo effects of LPS would, on becoming aware of the above, immediately suspect that these trials essentially showed that TNF is what transmits the broad spectrum of harmful effects caused by LPS. This was formally shown when the effects of TNF in tumor patients were compared to those of LPS in normal volunteers [71]. The outcome was consistent with what had been proposed, for malaria toxin as well as LPS, in conjunction with the Sloan-Kettering group, some years earlier [5,26]. 
Another equally unintentional scientific consequence of the failure of these trials was that it made much rTNF, generated in anticipation of a market that did not eventuate, available for basic research into its functions and properties. A number of companies found themselves with large stocks of what they evidently regarded as valueless material, and for a short while it was made freely available for basic research purposes. For example, $60 \mathrm{mg}$, a massive amount in laboratory terms, was donated to the author's laboratory in 1987. Basic research into no other inflammatory cytokine received this competitive advantage, which allowed, as well as much in vitro work, the extensive in vivo experimentation lacking in the lymphotoxin (LT) or interleukin-1 (IL-1) literatures.

\section{Investigating disease by assaying for TNF in serum and cell supernatants}

\subsection{Malaria and sepsis}

Once the cloning of TNF had been achieved in 1985 [34], the earlier functional assays for TNF were inevitably soon superseded by ELISA methods. Apart from their molecular specificity, these assays allowed many more samples to be tested. A preliminary report on a number of infections appeared in 1986 [72]. This was followed by more detailed accounts of levels of circulating TNF from both sepsis $[73,74]$ and malaria $[75,76]$ directly correlating with degree of illness.

\subsection{Viral diseases}

Although it had been proposed earlier, from outside the field [77], that severe viral disease, including influenza, arose from excessive production of TNF and similar cytokines, as late as 1993 mainstream virologists still generally considered that invasion and destruction of functionally important cells by the pathogen was a more likely mechanism [78]. Yet the widely acknowledged clinical confusion between malaria and influenza was difficult to deny. Moreover, the harmful effects of TNF, then gathering strength as the major argument for malarial disease pathogenesis, had been reported to generate what were termed influenza-like side effects when administered to tumor patients [67]. It was also noted that there was precedent for a virus inducing human peripheral blood mononuclear cells to release TNF [79]. Within a few years influenza A virus had also been shown to induce TNF $[80,81]$ and TNF was incriminated in the pathogenesis of the human disease caused by Dengue [82] Marburg [83] and Ebola [84] viruses.

In recent years the threat of $\mathrm{H} 5 \mathrm{~N} 1$ influenza infection has generated increased interest in the origins of the disease that it causes, and a number of papers have argued for an important role for $\mathrm{TNF}$ and related pro-inflammatory cytokines. Evidence includes (1) H5N1/97 viruses inducing much higher gene transcription of TNF than does H3N2 or H1N1 viruses [85]; (2) significant up-regulation of TNFrelated apoptosis-inducing ligand (TRAIL) and TNF mRNA in human monocyte-derived macrophages infected with H5N1/97 virus [86], and (3) high levels of inflammatory cytokines and chemokines being associated with fatal outcome [87]. Moreover, a reconstructed version of the strain of influenza virus responsible for massive human mortality in 1918-1919 has recently been reported to induce a strong pro-inflammatory cytokine response, including $\mathrm{TNF}$, during the fatal infections it causes in mice [88].

\subsection{Other systemic infectious diseases}

Increased levels of circulating TNF have now been measured soon after onset of illness in almost every severe systemic infectious state in which it has been sought. This includes those caused by non-erythrocytic protozoa, rickettsias, and bacteria (see Section 4.1, above). Some groups reported being unable to detect TNF directly (it rises and falls relatively quickly, and may have gone before serum samples are taken), but indirectly through the presence of cytokines it induces, such as IL-1 and interleukin-6 (IL-6). Though as equally informative as data from malaria, sepsis and influenza, references to TNF in these less common conditions are excluded from this review for space considerations.

\section{Attempts at TNF neutralization in a disease setting}

\subsection{Sepsis}

An obvious practical test of these concepts was to see whether giving patients a dose of an antibody that neutralizes TNF would cure sepsis or malaria, but as with using rTNF to treat tumors, it did not live up to expectations. It became apparent that neutralizing antibody to TNF was protective only when it was administered in animal sepsis models during a window beginning before, and ending very soon after, injection of endotoxin [35] or E. coli [63]. This was consistent with TNF being released early (serum peak 90 min after endotoxin injection) and having a short circulating half life (14-18 min) being rapidly taken into cells bearing its specific receptors [89]. A report that TNF release occurred very early in severe meningococcal sepsis, but was absent in the middle and end phases of fatal infections [73], indicated a similar pattern in patients.

Not surprisingly, therefore, little or no effect was achieved by administering a TNF-neutralizing molecule to patients with sepsis [90] or falciparum malaria [91] when their illness was well underway. These outcomes fitted the argument that it is too late to counter the inflammatory effects of TNF when patients are severely ill. In short, if they 
are ill today it is because of the TNF that was circulating yesterday, which by today has set the next stage of the cascade in motion. Hence, the focus of anti-cytokine therapy in sepsis has shifted to neutralising cytokines downstream from TNF, and often induced considerably later, such as migration inhibitory factor (MIF) and high-mobility group box 1 (HMGB1). Nevertheless, trials on preventing the Jarisch-Herxheimer reaction, in which neutralizing antiTNF antibody was given $30 \mathrm{~min}$ before penicillin (the trigger for LPS release following antibiotic-induced disintegration of the pathogen) to patients with louse-borne relapsing fever infection, prevented the post-penicillin cytokine release syndrome [92]. This establishes the involvement of TNF in essential preliminary stages of the acute cytokine release syndrome in humans.

\subsection{Rheumatoid arthritis and Crohn's disease}

Contemporary with the above research directed at understanding sepsis in TNF terms, a group that grew from the collaboration in London of Marc Feldman and Ravinda Maini documented their growing awareness that TNF was central to upregulating the cytokine cascade responsible for the chronic inflammatory response causing rheumatoid arthritis [93-96]. Parallel work established the same outcome for Crohn's disease [97]. It was inevitable, if the proposed dual activity of TNF on both host and pathogen [5] were an accurate prediction, that long-term use of TNF neutralization in these diseases would also increase growth of certain pathogens. This occurred, but has not appreciably dented the clinical success achieved in chronic inflammatory conditions by using this treatment. Clearly, the kinetics of TNF are quite different here than in sepsis, and treating these chronic inflammatory conditions by neutralising the presence or action of TNF has been the major practical success story of the cytokine field. A number of different approaches, marketed through an equal number of pharmaceutical companies, had, by early 2004, been estimated to have been used to treat close to a million patients [98]. From a scientific perspective, this important outcome, as well as the unwanted concomitant encouragement of pathogens, is clear evidence that TNF, originally isolated as a tumor killer, has a fundamental influence on both the host and pathogen in human disease.

\section{Summary}

As noted, Pubmed currently lists some 60,000 references to TNF, a molecule that rose to its present prominence through trusting and open collaboration between researchers in a number of apparently unrelated fields. TNF is now accepted to have roles in most aspects of biology. Now that a TNF superfamily of at least 19 members signalling through 29 receptors has been described [99], the challenge, actively being addressed by many groups, is to find more of practical worth within this unforeseen complexity.

\section{Postscript: TNF or TNF $\alpha$}

The cytokine lymphotoxin (LT), a relative of TNF that shares one of its receptors, was described [100] and cloned [101] earlier than was TNF. These two acronyms were universally used without confusion until 1985, when TNF began to be referred to as TNF $\alpha$ and LT as TNF $\beta$. While widely adopted, this terminology was questionable, since LT was the prior molecule.

Subsequently two LT forms referred to as LT $\alpha$ and LT $\beta$ were identified, superceding TNF $\beta$ and making TNF $\alpha$ an orphan term. Thus, although often currently used, TNF $\alpha$ now has no meaning other than the original term, TNF, and warrants abandoning.

\section{Acknowledgements}

The author owes gratitude to many colleagues, particularly (in chronological order) Frank Cox, Jean-Louis Virelizier and Betsy Richards, for advice and encouragement that steered him towards this fascinating approach to understanding disease.

\section{References}

[1] Carswell EA, Old LJ, Kassel RL, Green S, Fiore N, Williamson B. An endotoxin-induced serum factor that causes necrosis of tumors. Proc Natl Acad Sci USA 1975;72:3666-70.

[2] Old LJ, Clarke DA, Benacerraf B. Effect of Bacillus Calmette Guérin infection on transplanted tumours in the mouse. Nature 1959;184: 291-2.

[3] Shear MJ, Perrault A. Reactions of mice with primary subcutaneous tumors to the injection of a hemorrhage-producing bacterial polysaccharide. J Natl Cancer Inst 1944;4:461-8.

[4] Green S, Dobrjansky A, Carswell EA, Kassel RL, Old LJ, Fiore N, et al. Partial purification of a serum factor that causes necrosis of tumors. Proc Natl Acad Sci USA 1976;73:381-5.

[5] Clark IA, Virelizier J-L, Carswell EA, Wood PR. Possible importance of macrophage-derived mediators in acute malaria. Infect Immun 1981;32:1058-66.

[6] Clark IA, Richmond JE, Wills EJ, Allison AC. Intra-erythrocytic death of the parasite in mice recovering from infection with Babesia microti. Parasitol 1977;75:189-96.

[7] Salvin SB, Ribi E, Granger DL, Youngner JS. Migration inhibitory factor and type II interferon in the circulation of mice sensitized with mycobacterial components. J Immunol 1975;114:354-9.

[8] Clark IA, Allison AC, Cox FE. Protection of mice against Babesia and Plasmodium with BCG. Nature 1976;259:309-11.

[9] Clark IA, Cox FE, Allison AC. Protection of mice against Babesia spp. and Plasmodium spp. with killed Corynebacterium parvum. Parasitol 1977;74:9-18.

[10] Halpern BN, Biozzi G, Stiffel C, Mouton D. Inhibition of tumour growth by abministration of killed Corynebacterium parvum. Nature 1966;212:853-4.

[11] Dubos RJ, Schaedler RW. Effect of cellular constituents of Mycobacteria on the resistance of mice to heterologous infection. J Exp Med 1957;106:703-9.

[12] Howard JG, Biozzi G, Halpern BN, Stiffel C, Mouton D. The effect of Mycobacterium tuberculosis (BCG) infection on the resistance of 
mice to bacterial endotoxin and Salmonella enteritidis infection. Brit J Exp Path 1959;40:281-90.

[13] Collins FM, Scott MT. Effect of Corynebacterium parvum on the growth of Salmonella enteritidis in mice. Infect Immun 1974; 9:863-9.

[14] Swartzberg JE, Krahenbuhl JL, Remington JS. Dichotomy between macrophage activation and degree of protection against Listeria monocytogenes and Toxoplasma gondii in mice stimulated with Corynebacterium parvum. Infect Immun 1975;12:1037-43.

[15] Smrkovski LL, Larson CL. Effect of treatment with BCG on the course of visceral leishmaniasis in BALB/c mice. Infect Immun 1977;16:249-57.

[16] Clark IA, Cowden WB. The pathophysiology of falciparum malaria. Pharmacol Ther 2003;99:221-60.

[17] Suter E, Ullman GE, Hoffman RG. Sensitivity of mice to endotoxin after vaccination with BCG (Bacillus Calmette-Guérin). Proc Soc Exp Biol (NY) 1958;99:167-9.

[18] Abernathy RS, Bradley GM, Spink WW. Increased susceptibility of mice with brucellosis to bacterial endotoxins. J Immunol 1958;81:271-5.

[19] Pirsch JB, Mika LA, van der Maaten MJ. Hyperreactivity of Coxiella burnetii infected guines pigs to subsequent injections of bacterial endotoxins. Proc Soc Exp Biol (NY) 1957;96:376-80.

[20] Clark IA. Protection of mice against Babesia microti with cord factor, COAM, zymosan, glucan, Salmonella and Listeria. Para Immunol 1979;1:179-96.

[21] Cox FEG. Protective immunity between malaria parasites and piroplasms in mice. Bull WHO 1970;43:325-36.

[22] Clark IA. Does endotoxin cause both the disease and parasite death in acute malaria and babesiosis? Lancet 1978;ii:75-7.

[23] Helson L, Green S, Carswell E, Old LJ. Effect of tumour necrosis factor on cultured human melanoma cells. Nature 1975;258:731-2.

[24] Green S, Dobrjansky A, Chiasson MA, Carswell E, Schwartz MK, Old LJ. Corynebacterium parvum as the priming agent in the production of tumor necrosis factor in the mouse. J Natl Cancer Inst 1977;59:1519-22.

[25] Clark IA, Chaudhri G. Tumour necrosis factor may contribute to the anaemia of malaria by causing dyserythropoiesis and erythrophagocytosis. Br J Haematol 1988;70:99-103.

[26] Clark IA. Suggested importance of monokines in pathophysiology of endotoxin shock and malaria. Klin Wochenschr 1982;60:756-8.

[27] Ross R. The Prevention of Malaria. London: John Murray; 1911, $101-4$.

[28] Taverne J, Bate CAW, Playfair JHL. Induction of TNF in vitro as a model for the identification of toxic malaria antigens. Lymphokine Res 1989;8:317-22.

[29] Bate CAW, Kwiatkowski D. A monoclonal antibody that recognizes phosphatidylinositol inhibits induction of tumor necrosis factor alpha by different strains of plasmodium falciparum. Infect Immun 1994; 62:5261-6.

[30] Tachado SD, Gerold P, McConville MJ, Baldwin T, Quilici D, Schwarz RT, et al. Glycosylphosphatidylinositol toxin of Plasmodium induces nitric oxide synthase expression in macrophages and vascular endothelial cells by a protein tyrosine kinase-dependent and protein kinase c-dependent signaling pathway. J Immunol 1996; 156:1897-907.

[31] Schofield L, Hewitt MC, Evans K, Siomos MA, Seeberger PH. Synthetic GPI as a candidate antitoxic vaccine in a model of malaria. Nature 2002;418:785-9.

[32] Butler T, Ho M, Acharya G, Tiwari M, Gallati H. Interleukin-6, gamma interferon, and tumor necrosis factor receptors in typhoid fever related to outcome of antimicrobial therapy. Antimicrob Agents Chemother 1993;37:2418-21.

[33] Fekade D, Knox K, Hussein K, Melka A, Lalloo DG, Coxon RE, et al. Prevention of Jarisch-Herxheimer reactions by treatment with antibodies against tumor necrosis factor alpha. N Engl J Med 1996;335: $311-5$.
[34] Aggarwal BB, Kohr WJ, Hass PE, Moffat B, Spencer SA, Henzel WJ, et al. Human tumor necrosis factor: production, purification, and characterization. J Biol Chem 1985;260:2345-54.

[35] Beutler B, Milsark IW, Cerami AC. Passive immunization against cachectin/tumor necrosis factor protects mice from lethal effects of endotoxin. Science 1985;229:869-71.

[36] Bringman TS, Aggarwal BB. Monoclonal antibodies to human tumor necrosis factors alpha and beta: application for affinity purification, immunoassays, and as structural probes. Hybridoma 1987;6:489507.

[37] Ehrke MJ, Ho RL, Hori K. Species-specific TNF induction of thymocyte proliferation. Cancer Immunol Immunother 1988;27: $103-8$.

[38] Le J, Vilcek J. Tumor necrosis factor and interleukin-1: cytokines with multiple overlapping biological activities. Lab Invest 1987;56: 234-48.

[39] Nathan C. Secretory products of macrophages. J Clin Immunol 1989;79:319-26.

[40] Engwerda CR, Mynott TL, Sawhney S, De Souza JB, Bickle QD, Kaye PM. Locally up-regulated lymphotoxin alpha, not systemic tumor necrosis factor alpha, is the principle mediator of murine cerebral malaria. J Exp Med 2002;195:1371-7.

[41] Grau GE, Fajardo LF, Piguet P-F, Allet B, Lambert P-H, Vassali P. Tumor necrosis factor (cachectin) as an essential mediator in murine cerebral malaria. Science 1987;237:1210-2.

[42] Taverne J, Tavernier J, Fiers W, Playfair JHL. Recombinant tumour necrosis factor inhibits malaria parasites in vivo but not in vitro. Clin Exp Immunol 1987;67:1-4.

[43] Clark IA, Hunt NH, Butcher GA, Cowden WB. Inhibition of murine malaria (Plasmodium chabaudi) in vivo by recombinant interferongamma or tumor necrosis factor, and its enhancement by butylated hydroxyanisole. J Immunol 1987;139:3493-6.

[44] Bermudez LE, Young LS. TNF, alone or in combination with IL-2, but not IFN-gamma, is associated with macrophage killing of Mycobacterium avium complex. J Immunol 1988;140:3006-13.

[45] Degre M, Bukholm G. Effect of tumor necrosis factor-alpha on infection with Salmonella typhimurium in a mouse model. J Biol Regul Homeost Agents 1990;4:157-61.

[46] Titus RG, Sherry B, Cerami A. Tumor necrosis factor plays a protective role in experimental murine cutaneous leishmaniasis. J Exp Med 1989;170:2097-104.

[47] Chang HR, Grau GE, Perchere JC. Role of TNF and IL-1 in infections with Toxoplasma gondii. Immunol 1990;69:33-7.

[48] Tokarevich NK, Prokopyev AA, Prokopyeva ED, Simbirtsev AS, Toropova BG, Daiter AB, et al. Role of tumor necrosis factor and interleukin-1 in the formation of resistance in experimental Q fever. Zh Mikrobiol Epidemiol Immunobiol 1992;5:46-7.

[49] Rothe J, Lesslauer W, Lotscher H, Lang Y, Koebel P, Kontgen F, et al. Mice lacking the tumour necrosis factor receptor- 1 are resistant to TNF-Mediated toxicity but highly susceptible to infection by listeria monocytogenes. Nature 1993;364:798-802.

[50] Clark IA, Cowden WB, Butcher GA, Hunt NH. Possible roles of tumor necrosis factor in the pathology of malaria. Am J Pathol 1987;129:192-9.

[51] Clark IA, Chaudhri G. Tumor necrosis factor in malaria-induced abortion. Am J Trop Med Hyg 1988;39:246-9.

[52] Rook GAW, Taverne J, Leveton C, Steele J. The role of gammainterferon, vitamin $\mathrm{D}_{3}$ metabolites and tumour necrosis factor in the pathogenesis of tuberculosis. Immunol 1987;62:229-34.

[53] Bhutta ZA, Mansoorali N, Hussain R. Plasma cytokines in paediatric typhoidal salmonellosis: correlation with clinical course and outcome. J Infect 1997;35:253-6.

[54] Raziuddin S, Abdalla RE, el Awad EH, al Janadi M. Immunoregulatory and proinflammatory cytokine production in visceral and cutaneous leishmaniasis. J Infect Dis 1994;170:1037-40.

[55] Arsenijevic D, Girardier L, Seydoux J, Chang HR, Dulloo AG. Altered energy balance and cytokine gene expression in a murine 
model of chronic infection with Toxoplasma gondii. Am J Physiol 1997;272:E908-17.

[56] Mege JL, Maurin M, Capo C, Raoult D. Coxiella burnetii - the Query fever bacterium - a model of immune subversion by a strictly intracellular microorganism. FEMS Microbiol Rev 1997;19:209-17.

[57] Nakane A, Yamada K, Hasegawa S, Mizuki D, Mizuki M, Sasaki S, et al. Endogenous cytokines during a lethal infection with Listeria monocytogenes in mice. FEMS Microbiol Lett 1999;175:133-42.

[58] Kawakami M, Pekala PH, Lane MD, Cerami A. Lipoprotein lipase suppression in 3T3-L1 cells by an endotoxin-induced mediator from exudate cells. Proc Natl Acad Sci USA 1982;79:912-6.

[59] Beutler B, Mahoney J, Le TN, Pekala P, Cerami A. Purification of cachectin, a lipoprotein lipase-suppressing hormone secreted by endotoxin-induced RAW 264.7 cells. J Exp Med 1985;161:984-95.

[60] Beutler B, Greenwald D, Hulmes JD, Chang M, Pan Y-C, Mathison J, et al. Identity of tumour necrosis factor and the macrophage-secreted factor cachectin. Nature 1985;316:552-4.

[61] Tracey KJ, Beutler B, Lowry SF, Merryweather J, Wolpe S, Milsark IW, et al. Shock and tissue injury induced by recombinant human cachectin. Science 1986;234:470-4.

[62] Tracey KJ, Lowry SF, Fahey TJ, Albert JD, Fong Y, Hesse D, et al. Cachectin/tumor necrosis factor induces lethal shock and stress hormone response in the dog. Surg Gynecol Obstet 1987;164: 415-22.

[63] Tracey KJ, Fong Y, Hesse DG, Manogue KR, Lee AT, Kuo GC, et al. Anti-cachectin/TNF monoclonal antibodies prevent septic shock during lethal shock bacteraemia. Nature 1987;330:662-4.

[64] Takeda K, Iwamoto S, Sugimoto H, Takuma T, Kawatani N, Noda M, et al. Identity of differentiation inducing factor and tumour necrosis factor. Nature 1986;323:338-40.

[65] Jakubowski AA, Casper ES, Gabrilove JL, Templeton M-A, Sherwin SA. Oettgen HF. Phase 1 trial of intramuscularly administered tumor necrosis factor in patients with advanced cancer. J Clin Oncol 1989;7:298-303.

[66] Creagan ET, Kovach JS, Moertel CG, Frytak S, Kvols LK. A phase 1 clinical trial of recombinant human tumor necrosis factor. Cancer 1988;62:2467-71.

[67] Steinmetz T, Schaadt M, Gähl R, Schenk V, Diehl V, Pfreundschuh M. Phase 1 study of 24-hour continuous intravenous infusion of recombinant human tumor necrosis factor. J Biol Resp Mod 1988;7:417-23.

[68] Bauer KA, Cate HT, Barzeger S, Spriggs DR, Sherman ML, Rosenberg RD. Tumor necrosis factor infusions have a procoagulant effect on the hemostatic mechanism of humans. Blood 1989;74:165-72.

[69] van der Poll T, Buller HR, Gate H, Wortel CH, Bauer KA, van Deventer SJH, et al. Activation of coagulation after administration of tumor necrosis factor to normal subjects. N Engl J Med 1990; 322:1622-7.

[70] Spriggs DR, Sherman ML, Michie H, Arthur KA, Imamura K, Wilmore D, et al. Recombinant human tumor necrosis factor administered as a 24-hour intravenous infusion. A phase 1 and pharmacologic study. J Natl Cancer Inst 1988;80:1039-44.

[71] Michie HR, Spriggs DR, Manogue KR, Sherman ML, Revhaug A, O'Dwyer ST, et al. Tumor necrosis factor and endotoxin induce similar metabolic responses in human beings. Surgery 1988;104: 280-6.

[72] Scuderi P, Sterling KE, Lam KS, Finlay PR, Ryan KJ, Ray CG, et al. Raised serum levels of tumour necrosis factor in parasitic infections. Lancet 1986;ii:1364-5.

[73] Waage A, Halstensen A, Espevik T. Association between tumour necrosis factor in serum and fatal outcome in patients with meningococcal disease. Lancet 1987;i:355-7.

[74] Damas P, Reuter A, Gysen P, Demonty J, Lamy M, Franchimont P. Tumor necrosis factor and interleukin-1 serum levels during severe sepsis in humans. Crit Care Med 1989;17:975-8.

[75] Kern P, Hemmer CJ, Van Damme J, Gruss H-J, Dietrich M. Elevated tumour necrosis factor alpha and interleukin-6 serum levels as markers for complicated Plasmodium falciparum malaria. Am J Med 1989;87:139-43.

[76] Kwiatkowski D, Hill AVS, Sambou I, Twumasi P, Castracane J, Manogue KR, et al. TNF concentration in fatal cerebral, non-fatal cerebral, and uncomplicated Plasmodium falciparum malaria. Lancet 1990;336:1201-4

[77] Clark IA, Cowden WB. Is TNF a key to acute infectious illness? Today's Life Sci 1989;1:26-9.

[78] Schnittler HJ, Mahner F, Drenckhahn D, Klenk HD, Feldmann H. Replication of Marburg virus in human endothelial cells. A possible mechanism for the development of viral hemorrhagic disease. J Clin Invest 1993;91:1301-9.

[79] Aderka D, Holtmann H, Toker L, Hahn T, Wallach D. Tumor necrosis factor induction by Sendai virus. J Immunol 1986;136:2938-42.

[80] Houde M, Arora DJS. Stimulation of tumor necrosis factor secretion by purified influenza virus neuraminidase. Cell Immunol 1990;129: 104-11.

[81] Gong JH, Sprenger H, Hinder F, Bender A, Schmidt A, Horch S, et al. Influenza-A virus infection of macrophages. Enhanced tumor necrosis factor-alpha (TNF-alpha) gene expression and lipopolysaccharide-triggered TNF-alpha release. J Immunol 1991;147:3507-13.

[82] Yadav M, Kamath KR, Iyngkaran N, Sinniah M. Dengue haemorrhagic fever and dengue shock syndrome: are they tumour necrosis factor-mediated disorders? FEMS Micro Immol 1991;89:45-50.

[83] Feldmann H, Bugany H, Mahner F, Klenk HD, Drenckhahn D, Schnittler HJ. Filovirus-induced endothelial leakage triggered by infected monocytes/macrophages. J Virol 1996;70:2208-14.

[84] Villinger F, Rollin PE, Brar SS, Chikkala NF, Winter J, Sundstrom JB, et al. Markedly elevated levels of interferon (IFN)-gamma, IFNalpha, interleukin (IL)-2, IL-10, and tumor necrosis factor-alpha associated with fatal Ebola virus infection. J Infect Dis 1999; 179:S188-91.

[85] Cheung CY, Poon LLM, Lau AS, Luk W, Lau YL, Shortridge KF, et al. Induction of proinflammatory cytokines in human macrophages by influenza A (H5N1) viruses: a mechanism for the unusual severity of human disease. Lancet 2002;360:1831-7.

[86] Zhou JF, Law HKW, Cheung CY, Ng IHY, Peiris JSM, Lau YL. Functional tumor necrosis factor-related apoptosis-inducing ligand production by avian influenza virus-infected macrophages. J Infect Dis 2006;193:945-53.

[87] de Jong MD, Simmons CP, Thanh TT, Hien VM, Smith GJ, Chau TN, et al. Fatal outcome of human influenza A (H5N1) is associated with high viral load and hypercytokinemia. Nat Med 2006;10 [Have epub only. Get pages].

[88] Kash JC, Tumpey TM, Proll SC, Carter V, Perwitasari O, Thomas MJ, et al. Genomic analysis of increased host immune and cell death responses induced by 1918 influenza virus. Nature 2006;443:578-81.

[89] DeForge LE, Nguyen DT, Kunkel SL, Remick DG. Regulation of the pathophysiology of tumor necrosis factor. J Lab Clin Med 1990; 116:429-38.

[90] Fisher CJ, Agosti JM, Opal SM, Lowry SF, Balk RA, Sadoff JC, et al. Treatment of septic shock with the tumor necrosis factor receptor:Fc fusion protein. N Engl J Med 1996;334:1697-702.

[91] Kwiatkowski D, Molyneux ME, Stephens S, Curtis N, Klein N, Pointaire P, et al. Anti-TNF therapy inhibits fever in cerebral malaria. Quart J Med 1993;86:91-8.

[92] Coxon RE, Fekade D, Knox K, Hussein K, Melka A, Daniel A, et al. The effect of antibody against TNF alpha on cytokine response in Jarisch-Herxheimer reactions of louse-borne relapsing fever. Quart J Med 1997;90:213-21.

[93] Buchan G, Barrett K, Turner M, Chantry D, Maini RN, Feldmann M. Interleukin-1 and tumour necrosis factor mRNA expression in rheumatoid arthritis: prolonged production of IL-1 alpha. Clin Exp Immunol 1988;73:449-55.

[94] Brennan FM, Chantry D, Jackson A, Maini R, Feldmann M. Inhibitory effect of TNF alpha antibodies on synovial cell interleukin-1 production in rheumatoid arthritis. Lancet 1989;2:244-7. 
[95] Feldmann M, Brennan FM, Chantry D, Haworth C, Turner M, Abney $\mathrm{E}$, et al. Cytokine production in the rheumatoid joint: implications for treatment. Ann Rheum Dis 1990;49:480-6.

[96] Maini RN, Elliott MJ, Brennan FM, Feldmann M. Beneficial effects of tumour necrosis factor-alpha (TNF-alpha) blockade in rheumatoid arthritis (RA). Clin Exp Immunol 1995;101:207-12.

[97] van Dullemen HM, van Deventer SJ, Hommes DW, Bijl HA, Jansen J, Tytgat GN, et al. Treatment of Crohn's disease with anti-tumor necrosis factor chimeric monoclonal antibody (cA2). Gastroenterology 1995;109:129-35.

[98] Vilcek J, Feldmann M. Historical review: cytokines as therapeutics and targets of therapeutics. Trends Pharm Sci 2004;25:201-9.

[99] Aggarwal BB. Signalling pathways of the TNF superfamily: a double-edged sword. Nat Rev Immunol 2003;3:745-56.

[100] Ruddle NH, Waksman BH. Cytotoxic effect of lymphocyteantigen interaction in delayed hypersensitivity. Science 1967;157: 1060-2.

[101] Gray PW, Aggarwal BB, Benton CV, Bringman TS, Henzel WJ, Jarrett JA, et al. Cloning and expression of the cDNA for human lymphotoxin: lymphokine with tumor necrosis activity. Nature $1984 ; 312: 721-4$.

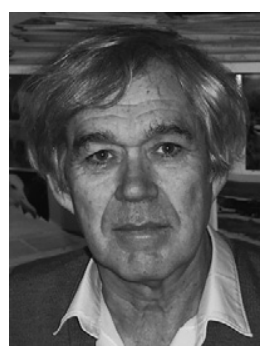

Ian Clark's first degree was in Veterinary Science at the University of Queensland in Australia. His $\mathrm{PhD}$ was in basic immunology at the Royal College of Surgeons in London, and he undertook cytokine research at the MRC Clinical Research Centre at Harrow, where he began the concept that tumour necrosis factor and functionally-related cytokines had roles in the host's protective response against invading organisms, and also in causing disease pathology. On returning to Australia he has continued his work on inflammatory cytokines in disease pathogenesis, for which he was awarded a University of London DSc. He is at the School of Biochemistry and Molecular Biology at the Australian National University in Canberra, where he holds a Professoriallevel NHMRC Research Fellowship and works on the role of inflammatory cytokines in disease pathophysiology. 